$\xi=-1$ 圆

\title{
Early Warning System in Mobile-Based Impacted Areas
}

\author{
Rahadian Irvan Moch. Taufiq ${ }^{1}$, Cepy Slamet ${ }^{1}$, Rian Andrian ${ }^{1}$, Hilmi Aulawi ${ }^{2}$, Muhammad Ali Ramdhani ${ }^{1}$ \\ ${ }^{I}$ Department of Informatics, UIN SunanGunungDjati Bandung, Indonesia \\ ${ }^{2}$ Department of Industrial Engineering, Sekolah Tinggi TeknologiGarut, Indonesia \\ *Corresponding author E-mail:cepy_lucky@uinsgd.ac.id
}

\begin{abstract}
Indonesia is a country prone to earthquake for Indonesia is located between three tectonic plates. Some natural disasters of earthquake caused have a big number of victims. This is due to the ineffectiveness of current early warning system since it still uses conventional way. This study is aimed to create a system that can deliver direct information about earthquake to the people of easy-using mediaand provide direction to the nearest evacuation site to them. Method of system design applies prototype development method. The applied system uses Google Maps API as a tool to trace the user's location and the evacuation site. In addition, the system will use firebase as a tool of notification delivery.
\end{abstract}

Keywords: early warning system, mobile-based, GPS.

\section{Introduction}

Earthquake activity in Indonesia is regarded to be very high, on average 400 times each month. From the year 1991 to 2007, 24time big earthquakes were recorded, including Aceh earthquake on26 December 2004 with the magnitude of 9.3 RS. The earthquake was followed by a massive tsunami that caused a hundred thousand deaths and caused property loss of trillions of rupiah. Another disaster is Yogyakarta earthquake on May 26, 2006 that caused severe infrastructure damage. Based on the data, the prompt accurate provision and service of earthquake information has a great importance for both emergency and mitigation efforts. Since early 2005, Indonesia through 16 related institutions including Indonesian Agency for Meteorological, Climatological and Geophysics (Badan Meteorologi, Klimatologi, dan Geofisika or simply BMKG) assisted by some donor countries has been developing a tsunami early warning system or called Indonesia Tsunami Early Warning System (Ina TEWS) which is aimed at reducing the risk of tsunami through warning tsunami occurrence a while after a major earthquake in the sea. To support the system, there have been installed 113 earthquake monitoring systems of 160 systems (in late 2008) and some other types of supporting equipment. Since the establishment of Ina TEWS, there have been gathered a lot of earthquake and tsunami data and information[1].

According to researchers, early warning for earthquake area begins with implementing ShakeAlert concept. ShakeAlert was established in 2006 and started to send warning signals to test users in California in 2012. ShakeAlert is operated by The Californian Integrated Seismic Network (CISN) to monitor the earthquakes occurrence in the west coast of the United States. CISN has spreader over 400 high-quality ground movement sensors operated by the USGS in collaboration with California Government, California Institute of Technology, and University of California, Berkeley. The work system of ShakeAlertie the user testers will receive warnings via computer applications in both audio and visual alerts. When ShakeAlert detects an earthquake, a map will appear on the computer screen to show the location of an earthquake and a wave that moves directly toward the user, and show the time left before the wave reaches the user's location and the estimated power of the shake[2].

In Indonesia, there are some early warning systems for all disasters including earthquakes that BMKG and National Agency for DisasterManagement (Indonesian: Badan Nasional PenanggulanganBencana, or simply BNPB) have provided. According to SOP (Standard Operation Procedure) in BMKG on the delivery guidance of earthquake and tsunami early warning, it takes about 5 minutes to send the information to people through some media such as website, TV, Radio, and deliver data to agencies related to natural disaster management. However, some people, especially those who work can not immediately know the information due to their own work activities. Moreover, if an earthquake or tsunami occurs, people will get confused where they should go due to lack of information on existing evacuation sites.

Accordingly, the accuracy in gaining and interpreting data is one of the main factors in data analysis system[3][4], and conveying the information properly. For further development, it is necessary to build an early warning system that has accurate data analysis to detect earthquake disaster in mobile-based affected areas. Mobilebased option is made considering that most people own mobile phone. On the other hand, the mobile software has the ability to present various information in multimedia, which facilitates the information delivery to its users[5]-[13]. This study is intended to design early warning for mobile-based earthquakes.

\section{Method}

This study applies prototype research method in its development process. Prototype can function as the first system, since both customers and developers like the prototype paradigm[14]. Software or application development method through an objectoriented approach with prototype method is one of software development method widely used. Through this prototype method developers and customers can interact with each other during the 
process of system creation[15]. In the next implementation phase, it is necessary to make adaptation evaluation of the software use. Adaptation testing is a test of technology acceptance level[16], which in this study the technology covers software and understanding the presented information.

\section{Result and Discussion}

The ICT presence has provided a lot of contributions for human work effectively and efficiently. ICT is a combination of information technology and human activity that uses computerized technology[17], and it is generally used to support operation and management [4]. Information system is a system that processes data in an organized way [18], information system has a high level of flexibility that allows development into a better system[19] Based on many research findings, the information system has advantages in terms of: good data accessibility[20], time efficiency[21], accuracy [22], supporting decision appropriately [23], more economical [24], broad accessibility [25], improving user understanding [26], improving productivity [27], providing good data and information [28], and used as data storage media [29].

ICT can implemented in warning system that the people use in responding natural disasters[30]. Early Warning System is a series of systems that serve to notify the occurrence of natural events This early warning system will tell people about any future disasters or other natural disasters[31]. Early warning to the community is one way to prevent a lot of victim's occurrence. A very common warning given to people is the siren sound to make people know it easily.

For Indonesia people, early warning system is very important considering that Indonesia is a country with the high threat of natural disaster. With this early warning system, it is expected to develop appropriate efforts in preventing or at least reducing the impact of natural disasters occurrence within the community. Making delays to deal with disasters can lead to greater losses in the community.

In disaster management cycle, early warning system of natural disasters is absolutely needed in the alerting phase, an early warning system for each data type, and the method of approach and instrumentation. The main goal of early warning system is providing a sense of security and comfort to people in all their activities although they stay in a location prone to natural disasters. When a natural disaster occurs, people have been given the means to prevent and deal with natural disasters. Fig. 1. presents the system architecture that works for earthquake disaster early warning.

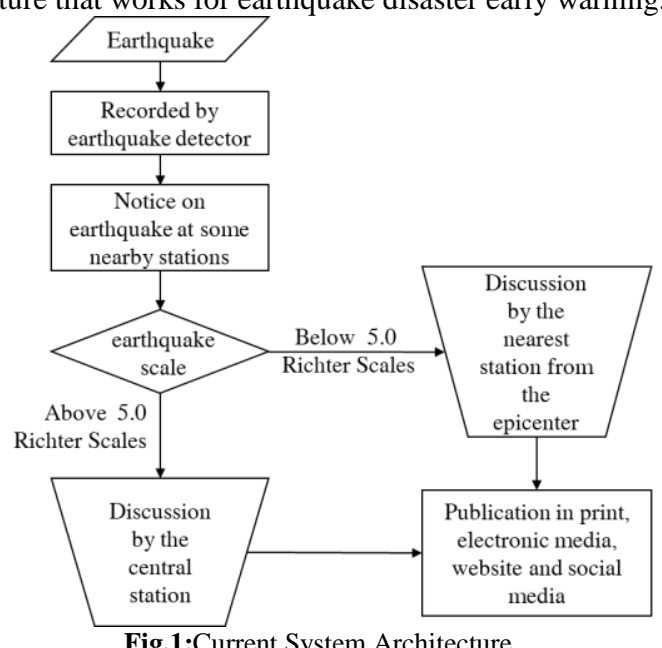

Fig.1:Current System Architecture

The running system has architecture like the Fig 1. The occurring earthquake is captured by BMKG's sensor and is grouped to be earthquake magnitudes. An earthquake that has below 5 RS of magnitude will be checked and discussed by the branch station, while an earthquake of above 5 RS magnitude will be directly checked by the central station.

Earthquakes early warning system of mobile-based impacted area uses the following system architecture. The process of sending data or warning of the application works when an earthquake occurs. The data that BMKG has received will be taken by web service application to get direct sending data to the user.

Users can directly receive warning information and other information when the data is successfully obtained by the web service. In addition to direct sending to the user, the retrieved data from BMKG is stored in the application database as a data history to see the previous earthquake data.

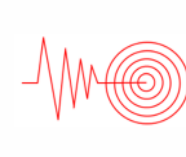

Occurring earthquake
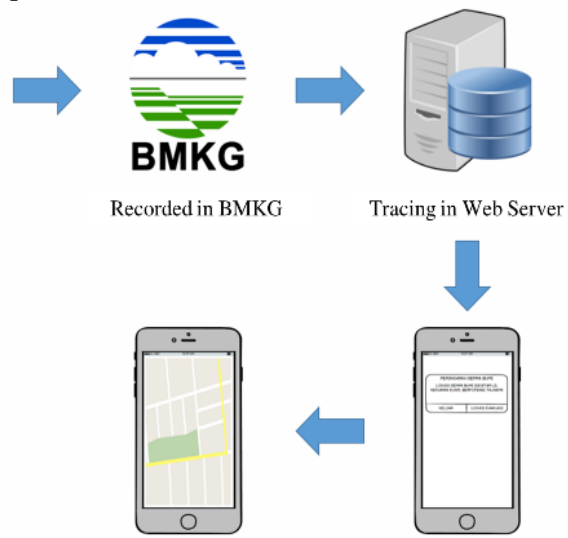

Direction to the Neares

Evacuation Point

Pop Up Warning in Users' Smartphone

Fig. 2:A Created System Architecture

Moreover, users can directly receive information about the nearest evacuation site from the user's location. The information of evacuation site comprises the location name and the nearest pathway to the location. Directions to nearby locations are shown in Google Maps app that specifically provides services to show directions or paths to the intended location.

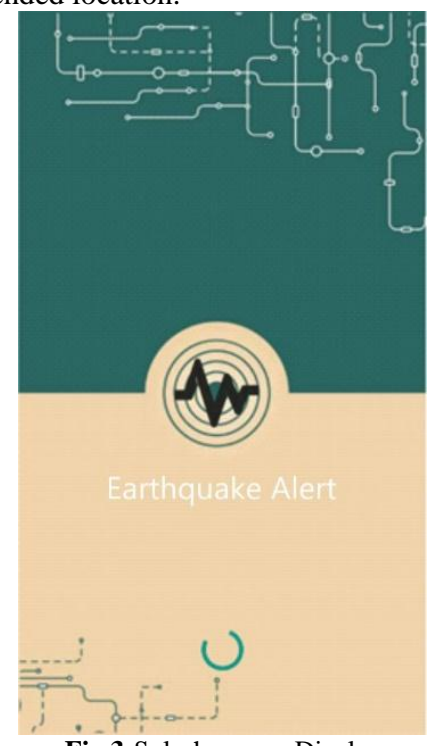

Fig 3:Splash-screen Display

After opening the application, splash-screen page will be displayed from which the display functions to register the user's device automatically into the data web service that belongs to the application (Fig. 3.). If the device has previously been registered or opened the application, the device message will tell that it has been registered, if the device firstly uses the app, the device message will tell that the device is successfully registered.

The main menu will appear after splash-screen display finish registering or checking the user's device status (Fig. 4.). Device messages successfully registered will appear in this main menu. Moreover, there are some other menus in this display: the last 
occurring earthquake data, the earthquake history menu, the see map menu, the first management menu and the about the application menu.

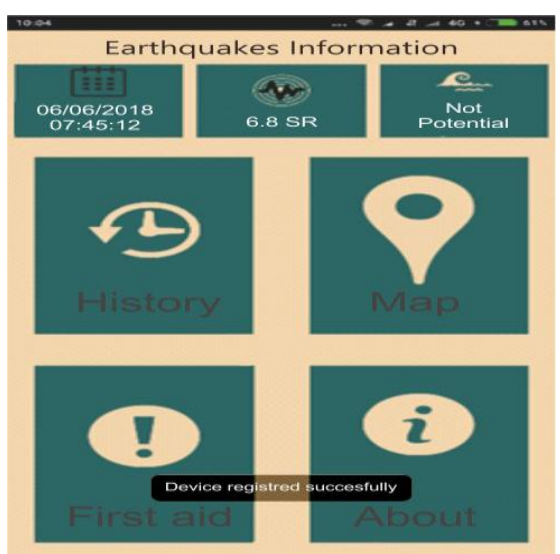

Fig 4:Main Menu Display

If web service application receives earthquake data from BMKG, the application will immediately forward the information to the user by sending warning or pop up messages (Fig. 5.). In addition to receiving pop up messages, this type of warning is also accompanied by alarm sound.

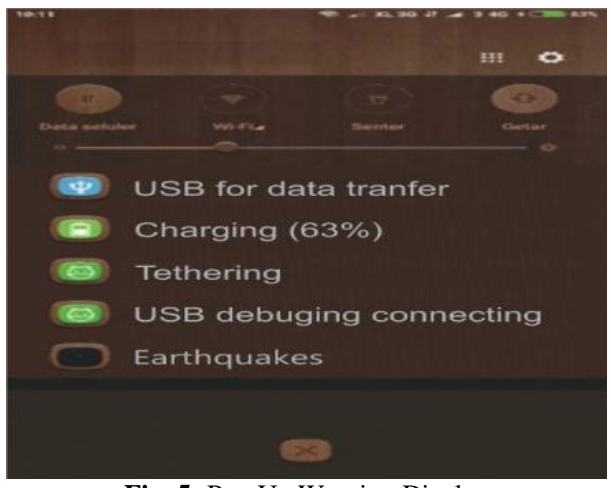

Fig. 5: Pop Up Warning Display

Moreover, the application will show the user's location together with the nearest evacuation point that is around the user (Fig. 6.) Users only need to select the nearest location to their position and press the help button.

Furthermore, the application will immediately show the direction to the nearest evacuation point selected by the user in Google Maps application (Fig. 7.). The shown direction includes the direction of the intended turns direction, the crowded point and the estimated time to reach the evacuation site by vehicle or on foot.

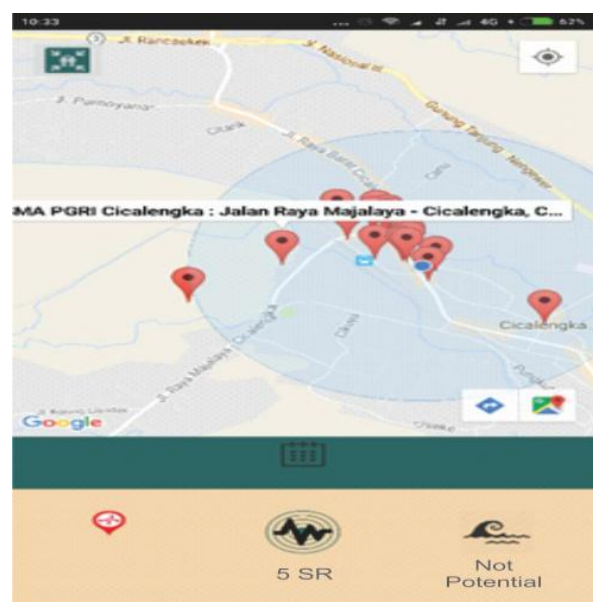

Fig. 6:Map and Evacuation Location Display

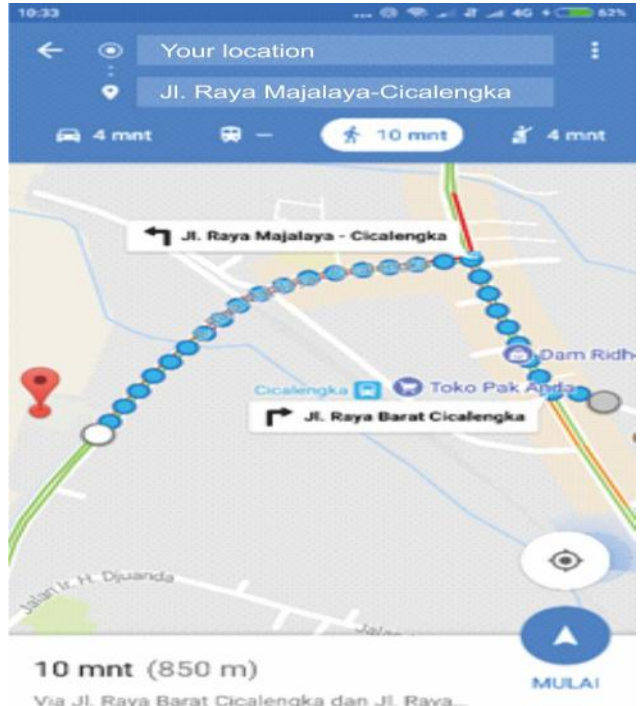

Fig. 7:Direction Display to Evacuation Site

\section{Conclusion}

Early warning system for earthquakes in mobile-based affected areas is designed as a system that provide information about the things that are necessary for saving people. The design of mobilebased early warning system is done by easy-using and understanding media for people such as gadget or smartphone devices which almost all people currently own them through providing information about the nearest evacuation points from the users' location, to provide certainty to the people suffer from earthquake natural disaster to find evacuation points.

\section{References}

[1] R. I. Sari and H. Vidiarina, Pedoman Pelayanan Peringatan Dini Tsunami. Jakarta: BMKG, 2012.

[2] USGS, ShakeAlert: An Earthquake Early Warning System for the United States West Coast. California: USGS, 2016.

[3] K. Suryadi and M. A. Ramdhani, Sistem Pendukung Keputusan. Bandung: Remaja Rosdakarya, 2002.

[4] M. A. Ramdhani, Metodologi Penelitian untuk Riset Teknologi Informasi. Bandung: UIN Sunan Gunung Djati Bandung, 2013.

[5] M. A. Ramdhani and E. R. Wulan, "The Analysis of Determinant Factors In Software Design For Computer Assisted Instruction," Int J. Sci. Technol. Res., vol. 1, no. 8, pp. 69-73, 2012.

[6] I. Helsy, Maryamah, I. Farida, and M. A. Ramdhani, "Volta-Based Cells Materials Chemical Multiple Representation to Improve Ability of Student Representation," J. Phys. Conf. Ser., vol. 895, no. 1, p. 012010, 2017.

[7] Sari, F. S. Irwansyah, I. Farida, and M. A. Ramdhani, "Using Android-Based Educational Game for Learning Colloid Material Using Android-Based Educational Game for Learning Colloid Material," J. Phys. Conf. Ser., vol. 895, no. 1, p. 012012, 2017.

[8] F. S. Irwansyah, I. Lubab, I. Farida, and M. A. Ramdhani, "Designing Interactive Electronic Module in Chemistry Lessons," J. Phys. Conf. Ser., vol. 895, no. 1, p. 012009, 2017.

[9] R. Aisyah, I. A. Zakiyah, I. Farida, M. A. Ramdhani, B. A, and D. C, "Learning Crude Oil by Using Scientific Literacy Comics," J. Phys. Conf. Ser., vol. 895, no. 1, p. 012011, 2017.

[10] I. Farida, I. Helsy, I. Fitriani, and M. A. Ramdhani, "Learning Material of Chemistry in High School Using Multiple Representations," IOP Conf. Ser. Mater. Sci. Eng., vol. 288, no. 1 , p. 012078,2018

[11] F. S. Irwansyah, Y. M. Yusuf, I. Farida, and M. A. Ramdhani, "Augmented Reality (AR) Technology on the Android Operating System in Chemistry Learning," IOP Conf. Ser. Mater. Sci. Eng., vol. 288, no. 1, p. 012068, 2018.

[12] S. Sari, D. M. Aryana, C. Z. Subarkah, and M. A. Ramdhani, "Multimedia Based on Scientific Approach for Periodic System of Element," IOP Conf. Ser. Mater. Sci. Eng., vol. 288, no. 1, p. 
012137, 2018.

[13] F. S. Irwansyah, C. Slamet, and M. A. Ramdhani, "Analysis of Determinant Factors in Selecting Laboratory Equipment in Chemistry Education Experiment," Chem. Eng. Trans., vol. 63, pp. 793-798, 2018.

[14] D. S. Maylawati, M. A. Ramdhani, and A. S. Amin, "Tracing the Linkage of Several Unified Modelling Language Diagrams in Software Modelling Based on Best Practices," Int. J. Eng. Technol., vol. 7, no. 2.29, pp. 776-780, 2018.

[15] R. S. Pressman, Software Engineering: A Practitioner's Approach, 7th ed. New York: McGraw-Hill, 2011.

[16] M. A. Ramdhani, H. Aulawi, A. Ikhwana, and Y. Mauluddin "Model of green technology adaptation in small and medium-sized tannery industry," J. Eng. Appl. Sci., vol. 12, no. 4, pp. 954-962, 2017.

[17] W. Darmalaksana, M. A. Ramdhani, R. Cahyana, and A. S. Amin, "Strategic Design of Information System Implementation at University," Int. J. Eng. Technol., vol. 7, no. 2.29, pp. 787-791, 2018.

[18] D. S. Maylawati, W. Darmalaksana, and M. A. Ramdhani, "Systematic Design of Expert System Using Unified Modelling Language," IOP Conf. Ser. Mater. Sci. Eng., vol. 288, no. 1, p. 012047, 2018.

[19] H. Aulawi, M. A. Ramdhani, C. Slamet, H. Ainissyifa, and W Darmalaksana, "Functional Need Analysis of Knowledge Portal Design in Higher Education Institution," Int. Soft Comput., vol. 12, no. 2, pp. 132-141, 2017.

[20] M. A. Ramdhani, D. S. Maylawati, A. S. Amin, and H. Aulawi, "Requirements Elicitation in Software Engineering," Int. J. Eng. Technol., vol. 7, no. 2.29, pp. 772-775, 2018.

[21] A. Pamoragung, K. Suryadi, and M. A. Ramdhani, "Enhancing the implementation of e-Government in indonesia through the highquality of virtual community and knowledge portal," in Proceedings of the European Conference on e-Government, ECEG, 2006, pp. 341-348.

[22] C. Slamet, R. Andrian, D. S. Maylawati, W. Darmalaksana, and M. A. Ramdhani, "Web Scraping and Naïve Bayes Classification for Job Search Engine," vol. 288, no. 1, pp. 1-7, 2018.

[23] Y. A. Gerhana, W. B. Zulfikar, A. H. Ramdani, and M. A Ramdhani, "Implementation of Nearest Neighbor using HSV to Identify Skin Disease," IOP Conf. Ser. Mater. Sci. Eng., vol. 288, no. 1 , p. $012153,2018$.

[24] A. Rahman, C. Slamet, W. Darmalaksana, Y. A. Gerhana, and M. A. Ramdhani, "Expert System for Deciding a Solution of Mechanical Failure in a Car using Case-based Reasoning," IOP Conf. Ser. Mater. Sci. Eng., vol. 288, no. 1, p. 012011, 2018.

[25] C. Slamet, A. Rahman, M. A. Ramdhani, and W. Darmalaksana "Clustering the Verses of the Holy Qur'an Using K-Means Algorithm," Asian J. Inf. Technol., vol. 15, no. 24, pp. 5159-5162, 2016.

[26] D. S. Maylawati, M. A. Ramdhani, W. B. Zulfikar, I. Taufik, and W. Darmalaksana, "Expert system for predicting the early pregnancy with disorders using artificial neural network," 2017 5th Int. Conf. Cyber IT Serv. Manag. CITSM 2017, 2017.

[27] W. B. Zulfikar, Jumadi, P. K. Prasetyo, and M. A. Ramdhani, "Implementation of Mamdani Fuzzy Method in Employee Promotion System," IOP Conf. Ser. Mater. Sci. Eng., vol. 288, no. 1, p. 012147, 2018.

[28] D. S. Maylawati, M. A. Ramdhani, A. Rahman, and W. Darmalaksana, "Incremental technique with set of frequent word item sets for mining large Indonesian text data," 2017 th Int. Conf. Cyber IT Serv. Manag. CITSM 2017, pp. 1-6, 2017.

[29] A. Taofik, N. Ismail, Y. A. Gerhana, K. Komarujaman, and M. A Ramdhani, "Design of Smart System to Detect Ripeness of Tomato and Chili with New Approach in Data Acquisition," in IOP Conference Series: Materials Science and Engineering, 2018, vol. 288, no. 1, p. 012018.

[30] C. Slamet, A. Rahman, A. Sutedi, W. Darmalaksana, M. A Ramdhani, and D. S. Maylawati, "Social Media-Based Identifier for Natural Disaster," IOP Conf. Ser. Mater. Sci. Eng., vol. 288, no. 1, p. 012039,2018

[31] I. Priyadi and M. E. Wijaya, "Perancangan Alat Pendeteksi dan Peringatan Gempa Berpotensi Tsunami dengan Transjvjisi Sinyal Audio Melalui Media Jala-Jala Listrik," TEKNOSIA, vol. 2, no. 13, pp. 37-51, 2014 